\title{
A Uniquely Selective Inhibitor of the Mammalian Fetal Neuromuscular Nicotinic Acetylcholine Receptor
}

\author{
Russell W. Teichert, ${ }^{1}$ Jean Rivier, ${ }^{2}$ Josep Torres, ${ }^{2}$ John Dykert, ${ }^{2}$ Charleen Miller, ${ }^{2}$ and Baldomero M. Olivera ${ }^{1}$ \\ ${ }^{1}$ Department of Biology, University of Utah, Salt lake City, Utah 84112, and ${ }^{2}$ Clayton Foundation Laboratories for Peptide Biology, The Salk Institute, \\ La Jolla, California 92037
}

We have purified and characterized a novel conotoxin from the venom of Conus obscurus, which has the unique property of selectively and potently inhibiting the fetal form of the mammalian neuromuscular nicotinic acetylcholine receptor (nAChR) ( $\alpha 1 \beta 1 \gamma \delta$-subunits). Although this conotoxin, $\alpha \mathrm{A}$-conotoxin OIVB $(\alpha \mathrm{A}-\mathrm{OIVB})$, is a high-affinity antagonist ( $\mathrm{IC}_{50}$ of $\left.56 \mathrm{~nm}\right)$ of the fetal muscle nAChR, it has $>1800$-fold lower affinity for the adult muscle $\mathrm{nAChR}(\alpha 1 \beta 1 \epsilon \delta$-subunits $)$ and virtually no inhibitory activity at a high concentration on various neuronal $\mathrm{nAChRs}$ ( $\mathrm{IC}_{50}>100 \mu \mathrm{m}$ in all cases). The peptide (amino acid sequence, CCGVONAACPOCVCNKTCG), with three disulfide bonds, has been chemically synthesized in a biologically active form. Although the neuromuscular nAChRs are perhaps the most extensively characterized of the receptors/ion channels of the nervous system, the precise physiological roles of the fetal form of the muscle nAChR are essentially unknown. $\alpha \mathrm{A}-\mathrm{OIVB}$ is a potentially important tool for delineating the functional roles of $\alpha 1 \beta 1 \gamma \delta$ receptors in normal development, as well as in various adult tissues and in pathological states. In addition to its potential as a research tool, $\alpha \mathrm{A}$-OIVB may have some direct biomedical applications.

Key words: fetal; muscle; nAChR; acetylcholine; inhibitor; receptor

\section{Introduction}

The discovery of $\alpha$-bungarotoxin approximately four decades ago, which provided a means of isolating the nicotinic acetylcholine receptor (nAChR) from the electric ray, was a seminal discovery in the history of molecular neuroscience (Chang and Lee, 1963). As a consequence of that discovery, the nAChR at the neuromuscular junction was extensively characterized. It is known to form a heteropentamer consisting of two $\alpha 1$-subunits, single $\beta 1$ - and $\delta$-subunits, and either a $\gamma$ - or an $\epsilon$-subunit (Mishina et al., 1986; Changeux et al., 1992). In the fetal stage of development, mammalian muscle cells express nAChRs that consist of $\alpha 1 \beta 1 \gamma \delta$-subunits, but, in late gestation, the $\gamma$-subunit is replaced with the $\epsilon$-subunit ( $\alpha 1 \beta 1 \epsilon \delta$-subunits) (Mishina et al., 1986; Witzemann et al., 1987, 1989). The heteropentameric receptor forms an ion channel gated by the neurotransmitter acetylcholine, which opens the channel after binding at both the $\alpha / \delta$ and $\alpha / \gamma$ or $\alpha / \epsilon$ interfaces of the receptor (Blount and Merlie, 1989).

Although the $\gamma$-subunit of the neuromuscular nAChR is replaced by the $\epsilon$-subunit in mammalian muscle during late gestation, there are instances of fetal muscle nAChR expression in adult mammalian tissues. Under normal physiological condi-

Received Sept. 30, 2004; revised Nov. 15, 2004; accepted Nov. 16, 2004.

This work was supported by National Institutes of Health Program Project GM 48677. We thank Ron Kaiser for the automated synthesis of $\alpha \mathrm{A}-\mathrm{OIVB}$, Dr. Anthony Craig for MS analyses, Duane Pantoja for amino acid analyses, Wes Thorsson and Ray McKinsey for providing live specimens of C. obscurus, and Debbie Doan for preparation of Figures 1 and 2 .

Correspondence should be addressed to Russell W. Teichert, Department of Biology, University of Utah, 254 South 1400 East, Salt Lake City, UT 84112. E-mail: teichert@biology.utah.edu.

DOI:10.1523/JNEUROSCI.4065-04.2005

Copyright $\odot 2005$ Society for Neuroscience $\quad$ 0270-6474/05/250732-05\$15.00/0 tions, expression of the $\gamma$-subunit occurs in the thymus (Marx et al., 1989; Navaneetham et al., 2001) and extraocular muscle fibers (Horton et al., 1993). Nicotinic receptors with $\gamma$-subunits are also ectopically expressed under a number of pathological conditions; the $\gamma$-subunit is expressed in denervated muscle ( $\mathrm{Gu}$ and Hall, 1988; Witzemann et al., 1989) and muscle tissue associated with various neurogenic and myogenic disorders (Gattenloehner et al., 2002). It is also expressed in rhabdomyosarcoma, a pediatric soft-tissue cancer (Gattenloehner et al., 1998, 1999). In these various tissues, the physiological roles of the fetal muscle nAChR are essentially unknown. A ligand that could serve as a tool to elucidate the physiological roles of the fetal muscle nAChR would be of considerable value to neuroscientists. However, the characterized inhibitors of the muscle nAChR do not include ligands with such binding specificity.

We report the purification and characterization of a peptide toxin from the venom of the marine cone snail, Conus obscurus, that selectively inhibits the mammalian fetal muscle $\mathrm{nAChR}$ ( $\alpha 1 \beta 1 \gamma \delta$-subunits) with significantly higher affinity than the mammalian adult muscle nAChR ( $\alpha 1 \beta 1 \epsilon \delta$-subunits). This peptide, which we named $\alpha \mathrm{A}$-conotoxin OIVB $(\alpha \mathrm{A}$-OIVB), is unique with respect to its selectivity. This peptide toxin does not block any of the neuronal nAChR subtypes tested. The specificity of $\alpha \mathrm{A}$-OIVB for the fetal muscle nAChR makes it an important tool for delineating the functional roles of $\alpha 1 \beta 1 \gamma \delta$ receptors and further elucidating where and when these receptors may be present.

\section{Materials and Methods}

Biological specimens. C. obscurus specimens were collected near Oahu, Hawaii, by Ray McKinsey and Wes Thorsson (Hawaiian Malacological 
Society, Honolulu, HI). The majority of the specimens were found under flat coral slabs at depths of 60-90 feet

Purification of native peptide $\alpha A-O I V B$. Venom milked from C. obscurus $(5 \mu \mathrm{l})$ as described previously (Hopkins et al., 1995) was diluted to 25 $\mu \mathrm{l}$ with $15 \% \mathrm{~B} 70$ [70\% acetonitrile (ACN) in $0.1 \%$ trifluoroacetic acid (TFA) $]$ and applied to a $\mathrm{C}_{8}$ HPLC column $[2.1 \times 100 \mathrm{~mm}$; Brownlee Aquapore RP-300 (PerkinElmer Life Sciences, Emeryville, CA)] maintained at $40^{\circ} \mathrm{C}$. The peptide designated $\alpha \mathrm{A}$-OIVB was obtained from the absorbance peak marked by an arrow in Figure $1 \mathrm{~A}$ by fractionation of 50 $\mu \mathrm{l}$ aliquots on the analytical column eluted with gradients of $\mathrm{ACN}$ in $0.1 \%$ TFA at $40^{\circ} \mathrm{C}$, as described previously (Teichert et al., 2004). The peptide was reapplied to the same $\mathrm{C}_{8}$ column and eluted with the same buffer system using the gradient shown in Figure $1 B$, leading to further purification.

Peptide synthesis. The peptide $\alpha \mathrm{A}-\mathrm{OIVB}$ was synthesized automatically on a methylbenzydrylamine resin $(2 \mathrm{~g}, 0.76 \mathrm{~mm} / \mathrm{g})$ (Stewart et al., 1976). The following side chain-protected t-butoxycarbonyl (Boc)-amino acids were used: hydroxyproline-benzyl [Hypro(Bzl)]; cysteine-4-methoxybenzyl; asparagine-xanthyl [Asn(Xan)]; and lysine-2-chorobenzyloxycarbonyl. $\mathrm{N}^{\alpha}$-Boc-amino acids were coupled in 2.5-fold excess via 1,3-diisopropylcarbodiimide in dichloromethane (DCM) and/or dimethylformamide. Asn (Xan) was coupled in the presence of a 1.5-fold excess of 1-hydroxybenzotriazole. Hypro(Bzl) was coupled using (benzotriazol-1-yl-oxy)-tris(dimethylamino)-phosphonium hexafluoro-phosphate. Deblocking of the Boc group was accomplished with 50\% TFA in DCM in the presence of $1 \%$ 1,2-ethanedithiol for $20 \mathrm{~min}$. The peptido-resin (4.5 g) was treated with hydrofluoric acid containing anisole ( $10 \% \mathrm{v} / \mathrm{v})$ and methylethylsulfide $(5 \%$ $\mathrm{v} / \mathrm{v}$ ) for $0.5 \mathrm{~h}$ at $-20^{\circ} \mathrm{C}$ and $1.0 \mathrm{~h}$ at $0^{\circ} \mathrm{C}$ to yield the fully deprotected peptide, which precipitated in ether. The peptide was separated from the cleaved resin by filtration after dissolution in $40 \%$ acetic acid.

Peptide cyclization and biochemical characterization. The $\alpha \mathrm{A}$-OIVB peptide extract was poured into $4.5 \mathrm{~L}$ of $0.1 \mathrm{M}$ ammonium acetate, and the $\mathrm{pH}$ was adjusted to 7.75 with ammonium hydroxide. The solution was stirred in an open beaker, slowly in the cold room. The air oxidation was monitored qualitatively by the Ellman test (Ellman, 1959) and HPLC (loss of absorbance of the starting material). Cyclization was determined to be complete after $3 \mathrm{~d}$, whereupon the $\mathrm{pH}$ was lowered to 5.0 with acetic acid $(\mathrm{AcOH})$. The solution was loaded onto $100 \mathrm{ml}$ of packed BioRex 70 beads $\left(\mathrm{H}^{+}\right.$form $)$in a $25 \times 200 \mathrm{~mm}$ column, and the resin was washed with $100 \mathrm{ml}$ of $5 \% \mathrm{AcOH}$; the peptide was then eluted from the resin with $50 \% \mathrm{AcOH}$. The peptide-containing fractions were combined, shell frozen, and lyophilized to yield $1.5 \mathrm{~g}$ of crude $\alpha \mathrm{A}$-OIVB. The crude peptide was loaded to a preparative HPLC (Miller and Rivier, 1996) cartridge $(5 \times 30 \mathrm{~cm})$ packed in the laboratory with reversed-phase $300 \AA$ Grace Vydac (Hesperia, CA) $\mathrm{C}_{18}$ silica (15-20 $\mu \mathrm{m}$ particle size). The $\alpha \mathrm{A}$-OIVB peptide eluted with a flow rate of $100 \mathrm{ml} / \mathrm{min}$ using a binary solvent system with a linear gradient of $0.3 \%$ solvent $\mathrm{B}$ per minute [solvent $\mathrm{A}$, $0.25 \mathrm{~N}$ triethylammonium phosphate (TEAP), $\mathrm{pH} 2.25$; solvent $\mathrm{B}, 60 \%$ ACN and $40 \%$ TEAP]. Desired fractions were subjected to a second purification step using TEAP, $\mathrm{pH} 6.5$, in a similar manner. The $\mathrm{pH}$ of purified fractions was adjusted to 2.5 with TFA, and the peptide-TEAP salt was exchanged to TFA using $0.1 \%$ TFA/ACN in the binary solvent system. The peptide at this step contained two components detected by capillary zone electrophoresis (CZE) using a previously described protocol (Miller and Rivier, 1998). The mixture was separated by ion exchange chromatography on an Amersham Biosciences (Arlington Heights, IL) Mono S 16/10 column $(1.6 \times 10 \mathrm{~cm} ; 10 \mu \mathrm{m}$ particle size $)$ using sodium chloride gradients in $10 \mathrm{~mm}$ sodium acetate (20\% acetonitrile/ $80 \%$ water) at $\mathrm{pH} 5.0$ and was desalted by HPLC using a gradient of ACN in $0.1 \%$ TFA. The desired component was determined by coelution with native $\alpha \mathrm{A}$-OIVB. Analytical HPLC screening of the purified fractions was performed on a Grace Vydac $C_{18}$ column $(0.46 \times 25 \mathrm{~cm} ; 5 \mu \mathrm{m}$ particle size; $300 \AA$ pore size) and an aqueous $0.1 \%$ TFA/ACN solvent system. The fractions containing $\alpha \mathrm{A}$-OIVB were pooled and lyophilized; the final yield was $29 \mathrm{mg}$. A comigration experiment of native and synthetic $\alpha \mathrm{A}$ OIVB was performed using CZE as described previously (Rivier, 2002) and as shown in Figure 2.

Equipment. Synthesis was performed using a Beckman Instruments (Fullerton, CA) System 990 Synthesizer. HPLC equipment for purifica- tion of synthetic peptide consisted of a PerkinElmer Life Sciences Series 410 Liquid Chromatograph and Waters Prep 500, Waters PrepPak 1000, and Waters 450 Detector set at $220 \mathrm{~nm}$. Ion exchange chromatography was performed on an Amersham Biosciences FPLC system. Native peptide was purified on an Agilent (Palo Alto, CA) 1090 Liquid Chromatograph.

Biological assays. $\alpha \mathrm{A}$-OIVB was tested by intramuscular injection of goldfish and intraperitoneal injection of 19-d-old Swiss Webster mice. $\alpha$-Conotoxin MI $(\alpha$-MI) was injected in the same manner to serve as a positive control and to provide comparisons of potency with $\alpha \mathrm{A}$-OIVB. Injections of $0.9 \% \mathrm{NaCl}$ served as negative controls. For each injection, the toxin was diluted in $0.9 \% \mathrm{NaCl}$ solution. Animals were observed for behavioral effects for a minimum of $3 \mathrm{~h}$ after injection.

Electrophysiology. To express each receptor, cRNA was prepared and injected into Xenopus oocytes as described previously (Cartier et al., 1996). Oocytes were injected 1-2 d after harvesting and used for voltageclamp recording 2-6 d after injection.

Voltage-clamp recording was done as described previously (Cartier et al., 1996). Briefly, oocytes were clamped at $-70 \mathrm{mV}$ with a two-electrode system and perfused with ND96 containing $1 \mu \mathrm{M}$ atropine to block endogenous muscarinic acetylcholine receptors and $0.2 \mathrm{mg} / \mathrm{ml}$ bovine serum albumin to reduce nonspecific adsorption of toxin. ND96 consisted of $96 \mathrm{~mm} \mathrm{NaCl}, 2.0 \mathrm{~mm} \mathrm{KCL}, 1.8 \mathrm{~mm} \mathrm{CaCl}_{2}, 1.0 \mathrm{~mm} \mathrm{MgCl}_{2}$, and $5 \mathrm{~mm}$ HEPES, pH 7.1-7.5. Acetylcholine (ACh)-gated currents were elicited by the following concentrations of ACh: 1 or $2 \mu \mathrm{M}$ for the human neuromuscular nAChR subtypes ( $\alpha 1 \beta 1 \epsilon \delta$ or $\alpha 1 \beta 1 \gamma \delta$-subunits); and $100 \mu \mathrm{M}$ for all neuronal nAChR subtypes. A $1 \mathrm{~s}$ pulse of ACh was applied to oocytes at a frequency of once per minute in each case.

To obtain dose-response curves and $\mathrm{IC}_{50}$ values, a minimum of five different concentrations of peptide toxin were applied to a given oocyte in a static bath $(30 \mu \mathrm{l}$ volume). Three different oocytes were tested to obtain a dose-response curve. The peptide was allowed to equilibrate with the receptors expressed in the oocytes for $5 \mathrm{~min}$ before pulsing with ACh. To establish that a peptide did not target a particular receptor, the peptide was tested at a concentration of $100 \mu \mathrm{M}$ on at least two different oocytes expressing the particular receptor.

Dose-response curves were fit to the following equation: \% Response $=100 /\left\{1+\left([\right.\right.$ toxin $\left.\left.] / \mathrm{IC}_{50}\right) n_{\mathrm{H}}\right\}$, where $n_{\mathrm{H}}$ is the Hill coefficient (GraphPad Software, San Diego, CA).

\section{Results}

\section{Purification of native $\alpha$ A-OIVB}

The marine snail from which $\alpha \mathrm{A}-\mathrm{OIVB}$ was purified, C. obscurus, is relatively small $(\sim 1 \mathrm{~cm})$, with miniscule amounts of venom in each duct (typically $\ll 0.5 \mu \mathrm{l}$ ). To minimize harvesting wild specimens, the venom from specimens kindly donated to us (by Wes Thorsson and Ray McKinsey) was obtained by milking as described in Materials and Methods. Because of the severely limiting amounts of venom available, major components of the venom were purified without any biological or biochemical assays and were directly sequenced. Wherever possible, the peptides were then chemically synthesized and folded, and further functional characterization was performed with synthetic peptide to spare harvesting more C. obscurus specimens from the wild.

Native $\alpha$ A-OIVB was isolated and purified from milked $C$. obscurus venom as shown in Figure 1 and described in Materials and Methods. The major peak, identified by the arrow in Figure $1 B$, was sequenced by Edman degradation to yield the amino acid sequence CCGVONAACPOCVCNKTCG, where $O$ is hydroxyproline. The average mass (1866.5) obtained for the peptide is consistent with an amidated $\mathrm{C}$ terminus and the sequence CCGVONAACPOCVCNKTCG-NH $\mathrm{N}_{2}$. This peptide shares the same cysteine pattern as previously characterized $\alpha \mathrm{A}$-conotoxins (Hopkins et al., 1995; Jacobsen et al., 1997; Teichert et al., 2004). Because of the shared cysteine pattern and subsequent characterization, we designated the peptide $\alpha \mathrm{A}$-OIVB. 

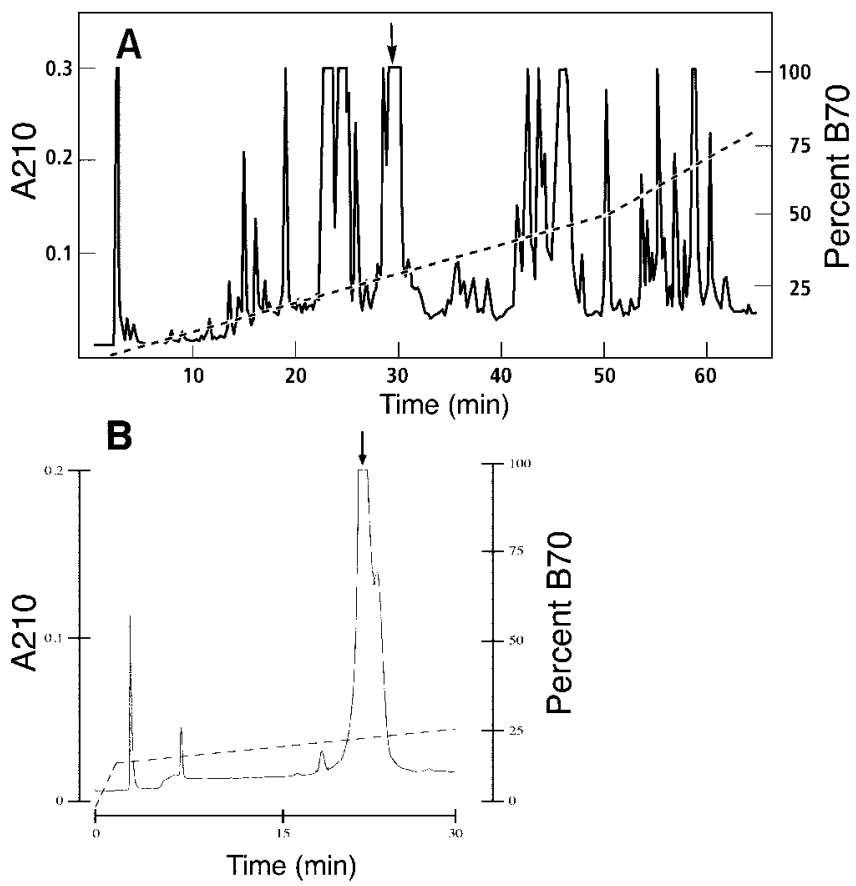

Figure 1. Purification of $\alpha \mathrm{A}-0 \mathrm{IV}$ B. $A$, Milked venom was fractionated on a reversed-phase $\mathrm{C}_{8}$ HPLC column. $B$, Further purification of the fraction marked by an arrow in $A$ provided $\alpha \mathrm{A}$-OIVB as the major peak, also marked by an arrow in $B$.

\section{Chemical synthesis and biochemical characterization of $\alpha$ A-OIVB}

$\alpha \mathrm{A}$-OIVB was synthesized as described in Materials and Methods. A comigration experiment of native and synthetic $\alpha \mathrm{A}-\mathrm{OIVB}$ was performed using CZE. A combined equal amount of both synthetic and native $\alpha \mathrm{A}-\mathrm{OIVB}$ eluted as a single symmetrical absorbance, shown in Figure 2. Fast atom bombardment mass spectrometry for $\alpha \mathrm{A}$-OIVB gave a monoisotopic mass of $(\mathrm{M}+$ $\mathrm{H})^{+} \mathrm{m} / \mathrm{z}=1864.71$; calculated $(\mathrm{M}+\mathrm{H})^{+} \mathrm{m} / \mathrm{z}=1864.67$. Amino acid analysis resulted in the expected ratios. We conclude from these experiments that synthetic and native $\alpha \mathrm{A}$-OIVB are chemically identical. Aliquots of $\alpha \mathrm{A}$-OIVB were quantified by amino acid analysis to ensure accuracy of results for biological and electrophysiological assays. Synthetic $\alpha$ A-OIVB was used for subsequent experiments.

\section{Biological assays}

$\alpha \mathrm{A}$-OIVB was assayed by intramuscular injection of goldfish. The toxin reproducibly caused a delayed but complete paralysis in goldfish at a concentration of $0.5 \mathrm{nmol} / \mathrm{g}$, in contrast to the absence of any observable effect when goldfish were injected with saline solution alone. Partial paralysis and impaired swimming were observed when lower concentrations of $\alpha \mathrm{A}$-OIVB were used. Goldfish that did not die from the toxin-induced paralysis recovered and resumed swimming within the $5 \mathrm{~h}$ postinjection observation period.

The peptide was also injected into mice; even at doses $>1$ $\mathrm{nmol} / \mathrm{g}$, no obvious behavioral or paralytic effects were observed.

\section{Electrophysiology: specificity of $\alpha$ A-OIVB for the mammalian fetal muscle $\mathbf{n A C h}$}

$\alpha \mathrm{A}$-OIVB was tested on Xenopus oocytes expressing either the human fetal ( $\alpha 1 \beta 1 \gamma \delta$-subunits) or adult ( $\alpha 1 \beta 1 \epsilon \delta$-subunits) neuromuscular $\mathrm{nAChR}$ by two-electrode voltage clamping, using

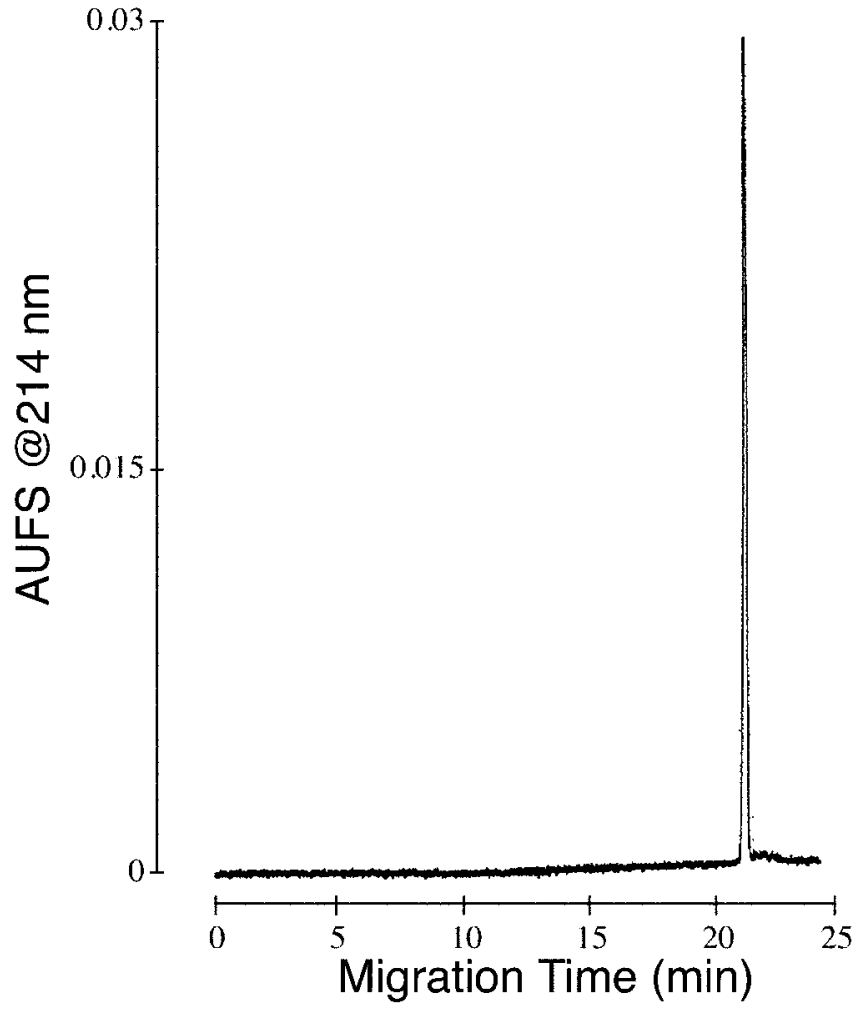

Figure 2. Comigration of synthetic and native $\alpha \mathrm{A}-\mathrm{OIVB}$ using $\mathrm{CZE}\left(100 \mathrm{~mm} \mathrm{Na}_{2} \mathrm{HPO}_{4}\right.$ buffer at $\mathrm{pH} 2.5$ and a voltage of $15 \mathrm{kV})$. AUFS, Absorbance units full scale.

a static-bath application of toxin. $\alpha$ A-OIVB potently inhibited the fetal muscle nAChR $(\alpha 1 \beta 1 \gamma \delta$-subunits) with $>1800$-fold higher affinity than its inhibition of the adult muscle nAChR ( $\alpha 1 \beta 1 \epsilon \delta$-subunits) (Fig. 3).

The high-affinity block of the fetal muscle nAChR by $\alpha \mathrm{A}$ $\operatorname{OIVB}\left(\mathrm{IC}_{50}\right.$ of $56 \mathrm{nM}$ ) is in contrast to its low affinity for a number of additional nicotinic acetylcholine receptors. We tested $\alpha \mathrm{A}$ OIVB on Xenopus oocytes expressing various neuronal nAChR subtypes to better define its targeting specificity. At a concentration of $100 \mu \mathrm{M}, \alpha \mathrm{A}$-OIVB did not significantly block most of the receptors tested. In all cases, at a concentration of $100 \mu \mathrm{M}, \alpha \mathrm{A}$ OIVB blocked $<50 \%$ of elicited response for each receptor tested, with the exception of the human fetal muscle nAChR, which it blocked completely. These experiments attest to the targeting specificity of $\alpha \mathrm{A}$-OIVB for the fetal subtype of the neuromuscular nAChR (Fig. 4).

\section{Discussion}

$\alpha \mathrm{A}$-OIVB, purified from the venom of C. obscurus, has $>1800$ fold higher affinity for the human fetal muscle nAChR than the human adult muscle nAChR. $\alpha \mathrm{A}$-OIVB does not target various neuronal nAChRs; thus, it appears to be a specific inhibitor of the fetal muscle $\mathrm{nAChR}$. The toxin causes a reversible neuromuscular paralysis after injection into goldfish.

Although numerous inhibitors of the neuromuscular nAChR have been characterized previously, none have proven to share with $\alpha \mathrm{A}$-OIVB the binding specificity for the fetal subtype of the mammalian muscle nAChR. $\alpha$-Bungarotoxin and numerous snake $\alpha$-neurotoxins bind both the $\alpha 1 \delta$ and $\alpha 1 \gamma$ interfaces of the muscle receptor with high affinity. Because of the high-affinity binding of the $\alpha 1 \delta$ interface, these are not selective for the fetal muscle nAChR. Toxins known as wagerlins from the pit viper 
- Human Fetal nAChR $(\alpha \beta \gamma \delta)$

- Human Adult nAChR $(\alpha \beta \varepsilon \delta)$

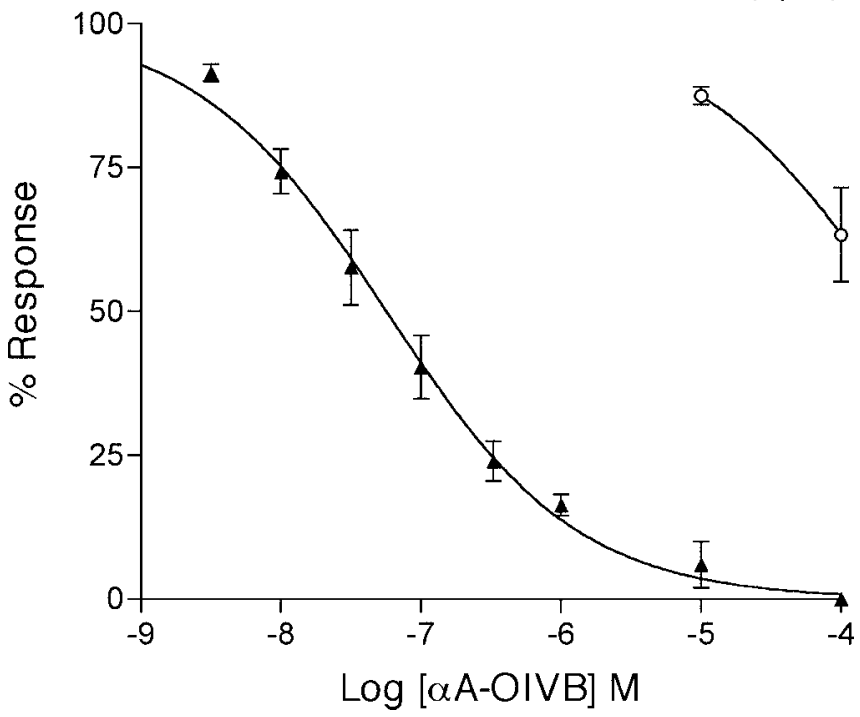

Figure 3. Dose-response of $\alpha \mathrm{A}-\mathrm{OIVB}$ on the human fetal and adult muscle $\mathrm{nAChR}$ by twoelectrode voltage-clamping Xenopus 0ocytes. Toxin was applied to oocytes in a static bath and allowed to equilibrate with receptors for 5 min before pulsing with ACh. $\alpha \mathrm{A}$-OIVB blocked the human fetal muscle nAChR (filled triangles) with an $\mathrm{IC}_{50}$ of $56 \mathrm{~nm}$ (44.2-72.4 nм; $95 \%$ confidence interval). In contrast, it blocked the human adult muscle nAChR (open circles) with an $\mathrm{IC}_{50}>100,000 \mathrm{~nm}$ ( $n \geq 3$ for each concentration tested).

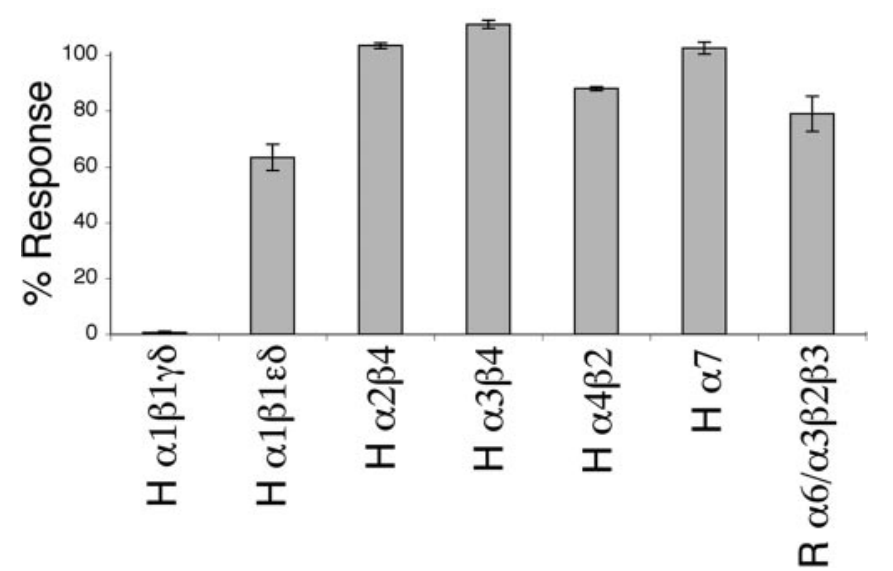

Figure 4. $\alpha$ A-OIVB was tested for specificity as an inhibitor against multiple nicotinic acetylcholine receptors by two-electrode voltage-clamping Xenopus 0ocytes. Toxin was applied at a concentration of $100 \mu \mathrm{m}$ to 00 cytes in a static bath and allowed to equilibrate for $5 \mathrm{~min}$ before pulsing with ACh and resuming perfusion of ND96 buffer. The bar graph represents the peak amplitude response after toxin application (error bars indicate \pm SEM) as a percentage of control responses. The inhibition of the fetal muscle nAChR ( $\alpha 1 \beta 1 \gamma \delta$-subunits) is in contrast to the relative lack of inhibition of various other $n A C h R s$. H, Human clone; $R$, rat clone. $n \geq 2$ oocytes for each nAChR tested.

Trimeresurus wagleri bind with 2000-fold higher affinity to the $\alpha 1 \epsilon$ interface of the adult receptor over the $\alpha 1 \delta$ and $\alpha 1 \gamma$ interfaces (McArdle et al., 1999), thus giving a subtype selectivity for neuromuscular nAChRs complementary to $\alpha \mathrm{A}$-OIVB. The $\alpha$-neurotoxin NmmI from Naja mossambica mossambica binds both the $\alpha 1 \delta$ - and $\alpha 1 \gamma$-subunit interfaces with $\sim 1000$-fold higher affinity than the $\alpha 1 \epsilon$ interface (Osaka et al., 1999). Curare and other curariform antagonists bind with relatively high affinity to both the $\alpha 1 \epsilon$ and $\alpha 1 \gamma$ interfaces of the mammalian muscle nAChR, whereas they bind with $\sim 100$-fold lower affinity to the $\alpha 1 \delta$ interface (Sine, 1993; Bren and Sine, 1997). Many of the $\alpha$-conotoxins bind with 10,000-fold higher affinity to the mammalian $\alpha 1 \delta$ interface than the $\alpha 1 \gamma$ interface (Groebe et al., 1995), whereas $\alpha$ A-conotoxins EIVA and EIVB block both the $\alpha 1 \delta$ and $\alpha 1 \gamma$ interfaces with equal affinity (Jacobsen et al., 1997). Notably absent among previously characterized antagonists of the neuromuscular $\mathrm{nAChR}$ are those that selectively inhibit the fetal muscle nAChR ( $\alpha 1 \beta 1 \gamma \delta$-subunits), i.e., antagonists that bind the $\alpha 1 \gamma$ subunit interface preferentially over the $\alpha 1 \delta$ and $\alpha 1 \epsilon$ interfaces of the adult form of the muscle receptor ( $\alpha 1 \beta 1 \epsilon \delta$-subunits).

Thus, $\alpha \mathrm{A}$-OIVB, with its selectivity for the fetal muscle $\mathrm{nAChR}$ versus the adult muscle $\mathrm{nAChR}$, fills the gap in specificity among various inhibitors of the $\mathrm{nAChR}$. Although expression of the $\gamma$-subunit of the $\mathrm{nAChR}$ in mammals is primarily in fetal muscle tissue, there are instances of $\gamma$-subunit expression in adult tissues, i.e., thymus and extraocular muscle fibers under normal conditions, and muscle tissue under various pathological conditions (Gu and Hall, 1988; Marx et al., 1989; Witzemann et al., 1989; Horton et al., 1993; Navaneetham et al., 2001; Gattenloehner et al., 2002). The physiological role of the fetal muscle nAChR is undefined under these conditions; $\alpha \mathrm{A}$-OIVB should prove useful in elucidating both the normal and pathological roles of $\gamma$-subunit expression in both fetal and adult mammals. Thus, the peptide provides a potential tool for inhibiting function of the fetal nAChR without disrupting its assembly and without disrupting the function or expression of the adult neuromuscular nAChR.

The sequences of the known $\alpha \mathrm{A}$-conotoxins are the following: $\alpha$ A-EIVA, GCCGPYONAACHOCGCKVGROOYCDROSGG\#; $\alpha$ A-EIVB, GCCGKYONAACHOCGCTVGROOYCDROSGG\#; $\alpha$ A-PIVA, GCCGSYONAACHOCSCKDROSYCGQ\#; and $\alpha$ AOIVA, CCGVONAACHOCVCKNTC\#; $\alpha$ A-OIVB, CCGVONAACPOCVCNKTCG\#, where $\mathrm{O}$ indicates hydroxyproline, and \# indicates amidation.

The subtype selectivity of $\alpha$ A-PIVA has not been analyzed. $\alpha \mathrm{A}$-OIVA was identified previously only as a low-affinity inhibitor of the adult $(\alpha 1 \beta 1 \epsilon \delta)$ muscle nAChR (Teichert et al., 2004). Additional characterization of $\alpha \mathrm{A}$-OIVB, $\alpha \mathrm{A}$-OIVA, and $\alpha \mathrm{A}$ PIVA has been initiated, including structure-function studies and a detailed analysis of the kinetics.

Although it may seem odd that a peptide from Conus venom targets specifically a fetal receptor as opposed to an adult receptor, a recent report on nicotinic acetylcholine receptors in pufferfish (Fugu rubripes) indicates that homologs of both the mammalian $\gamma$ - and $\epsilon$-subunits are expressed in muscle and gill in immature adult pufferfish, before full differentiation of sex organs (Jones et al., 2003). Thus, the fact that $\alpha \mathrm{A}-\mathrm{OIVB}$ was found in the venom of a fish-hunting Conus species can be rationalized if some of their fish prey express both $\gamma$-and $\epsilon$-subunits simultaneously in muscle and gill; this may explain the evolution of a conotoxin targeted to $\gamma$-subunit-containing receptors.

The specificity of $\alpha \mathrm{A}$-OIVB for the $\alpha 1 \gamma$-subunit interface of nAChRs confers an interesting phylogenetic profile of activity compared with other antagonists of neuromuscular nAChR subtypes. We injected $\alpha$-MI as a control when we performed the biological assays with $\alpha \mathrm{A}$-OIVB; $\alpha$-MI is highly specific for the $\alpha 1 \delta$-subunit interface (Sine et al., 1995). As expected, $\alpha$-MI elicited paralysis in goldfish (at a dose of $\sim 0.030 \mathrm{nmol} / \mathrm{g}$ under the conditions used) but was even more potent when injected into mice $(\sim 0.013 \mathrm{nmol} / \mathrm{g})$. In contrast, $\alpha \mathrm{A}$-OIVB paralyzed goldfish but elicited no obvious paralytic symptoms in mice, even when higher doses (up to $>1 \mathrm{nmol} / \mathrm{g}$ ) were used. However, $\alpha \mathrm{A}$-OIVB causes a high-affinity block of both human $\alpha 1 \beta 1 \gamma \delta$ receptors (as 
described above), as well as the homologous cloned rodent receptor (results not shown). Thus, it may be possible to use the peptide to assess effects of blocking $\gamma$-containing receptors in the thymus on the immune system in vivo, because the peptide does not paralyze the adult animal.

There are potential biomedical applications for the peptide, for example, the discovery that the fetal form of the muscle $\mathrm{nAChR}$ is expressed in rhabdomyosarcoma, a common form of pediatric soft-tissue sarcoma. The $\gamma$-subunit of the muscle $\mathrm{nAChR}$ has been proposed as a diagnostic marker for this form of cancer because it differentiates between rhabdomyosarcoma and other tumors, as well as normal tissue. The fetal form of the muscle nAChR has also been suggested as a possible drug target for rhabdomyosarcoma (Gattenloehner et al., 1998, 1999). Thus, $\alpha \mathrm{A}$-OIVB should be a useful ligand that has diagnostic and therapeutic potential, as well as a clear role for addressing questions regarding $\gamma$-subunit-containing $\mathrm{nAChRs.}$

\section{References}

Blount P, Merlie JP (1989) Molecular basis of the two nonequivalent ligand binding sites of the muscle nicotinic acetylcholine receptor. Neuron 3:349-357.

Bren N, Sine SM (1997) Identification of residues in the adult nicotinic acetylcholine receptor that confer selectivity for curariform antagonists. J Biol Chem 272:30793-30798.

Cartier GE, Yoshikami D, Gray WR, Luo S, Olivera BM, McIntosh JM (1996) A new $\alpha$-conotoxin which targets $\alpha 3 \beta 2$ nicotinic acetylcholine receptors. J Biol Chem 271:7522-7528.

Chang CC, Lee CY (1963) Isolation of neurotoxins from the venom of Bungarus multicinctus and their modes of neuromuscular blocking action. Arch Int Pharmacodyn Ther 144:241-257.

Changeux JP, Galzi JL, Devillers-Thiery A, Bertrand D (1992) The functional architecture of the acetylcholine nicotinic receptor explored by affinity labeling and site-directed mutagenesis. Q Rev Biophys 25:395-432.

Ellman GL (1959) Tissue sulfhydryl groups. Arch Biochem Biophys 82:70-77.

Gattenloehner S, Vincent A, Leuschner I, Tzartos S, Muller-Hermelink HK, Kirchner T, Marx A (1998) The fetal form of the acetylcholine receptor distinguished rhabdomyosarcomas from other childhood tumors. Am J Pathol 152:437-444.

Gattenloehner S, Dockhorn-Dworniczak B, Leuschner I, Vincent A, MullerHermelink HK, Marx A (1999) A comparison of MyoDl and fetal acetylcholine receptor expression in childhood tumors and normal tissues: implications for the molecular diagnosis of minimal disease in rhabdomyosarcomas. J Mol Diagn 1:23-31.

Gattenloehner S, Schneider C, Thamer C, Klein RC, Roggendorf W, Gohlke F, Niethammer C, Czub S, Vincent A, Muller-Hermelink HK, Marx A (2002) Expression of foetal acetylcholine receptor is restricted to type 1 muscle fibres in human neuromuscular disorders. Brain 125:1309-1319.

Groebe DR, Dumm JM, Levitan ES, Abramson SN (1995) $\alpha$-Conotoxins selectively inhibit one of the two acetylcholine binding sites of nicotinic receptors. Mol Pharmacol 48:105-111.

Gu Y, Hall ZW (1988) Characterization of acetylcholine receptor subunits in developing and in denervated mammalian tissue. J Biol Chem 263:12878-12885.
Hopkins C, Grilley M, Miller C, Shon K, Cruz LJ, Gray WR, Dykert J, Rivier J, Yoshikami D, Olivera BM (1995) A new family of Conus peptides targeted to the nicotinic acetylcholine receptor. J Biol Chem 270:22361-22367.

Horton RM, Manfredi AA, Conti-Tronconi BM (1993) The "embryonic" gamma subunit of the nicotinic acetylcholine receptor is expressed in adult extraocular muscle. Neurology 43:983-986.

Jacobsen R, Yoshikami D, Ellison M, Martinez J, Gray WR, Cartier GE, Shon KJ, Groebe DR, Abramson SN, Olivera BM, McIntosh JM (1997) Differential targeting of nicotinic acetylcholine receptors by novel $\alpha \mathrm{A}$ conotoxins. J Biol Chem 272:22531-22537.

Jones AK, Elgar G, Sattelle DB (2003) The nicotinic acetylcholine receptor gene family of the pufferfish, Fugu rubripes. Genomics 82:441-451.

Marx A, Kirchner T, Hoppe F, O'Connor R, Schalke B, Tzartos S, MüllerHermelink HK (1989) Proteins with epitopes of the acetylcholine receptor in epithelial cell cultures of thymus in myasthenia gravis. Am J Pathol 134:865-877.

McArdle JJ, Lentz TL, Witzemann V, Schwarz H, Weinstein SA, Schmidt JJ (1999) Waglerin-1 selectively blocks the epsilon form of the muscle nicotinic acetylcholine receptor. J Pharmacol Exp Ther 289:543-550.

Miller C, Rivier J (1996) Peptide chemistry: development of highperformance liquid chromatography and capillary zone electrophoresis. Biopolymers 40:265-316.

Miller C, Rivier J (1998) Analysis of synthetic peptides by capillary zone electrophoresis in organic/aqueous buffers. J Pept Res 51:444-451.

Mishina M, Takai T, Imoto K, Noda M, Takahashi T, Numa S, Methfessel C, Sakmann B (1986) Molecular distinction between fetal and adult forms of muscle acetylcholine receptor. Nature 321:406-411.

Navaneetham D, Penn AS, Howard JF, Conti-Fine BM (2001) Human thymuses express incomplete sets of muscle acetylcholine receptor subunit transcripts that seldom include the $\delta$ subunit. Muscle Nerve 24:203-210.

Osaka H, Malany S, Kanter JR, Sine SM, Taylor P (1999) Subunit interface selectivity of the $\alpha$-neurotoxins for the nicotinic acetylcholine receptor. J Biol Chem 274:9581-9586.

Rivier J (2002) Chromatographic methods. In: Synthesis of peptides and peptidomimetics, pp 630-650. Stuttgart, Germany: Georg Thieme Verlag.

Sine SM (1993) Molecular dissection of subunit interfaces in the acetylcholine receptor: identification of residues that determine curare selectivity. Proc Natl Acad Sci USA 90:9436-9440.

Sine SM, Kreienkamp H-J, Bren N, Maeda R, Taylor P (1995) Molecular dissection of subunit interfaces in the acetylcholine receptor: identification of determinants of $\alpha$-conotoxin MI selectivity. Neuron 15:205-211.

Stewart J, Pèna C, Matsueda GR, Harris K (1976) Some improvements in the solid phase synthesis of large peptides. In: The 14th European Peptide Symposium, pp 285-290. Wépion, Belgium: Editions de l'Université de Bruxelles, Bruxelles (Belgique).

Teichert RW, Rivier J, Dykert J, Cervini L, Gulyas J, Bulaj G, Ellison M, Olivera BM (2004) $\alpha$ A-Conotoxin OIVA defines a new $\alpha \mathrm{A}$-conotoxin subfamily of nicotinic acetylcholine receptor inhibitors. Toxicon 44:207-214.

Witzemann V, Barg B, Nishikawa Y, Sakmann B, Numa S (1987) Differential regulation of muscle acetylcholine receptor gamma- and epsilonsubunit mRNAs. FEBS Lett 223:104-112.

Witzemann V, Barg B, Criado M, Stein E, Sakmann B (1989) Developmental regulation of five subunit specific mRNAs encoding acetylcholine receptor subtypes in rat muscle. FEBS Lett 242:419-424. 